\title{
活動報告
}

\section{フェンタニル舌下錠使用時の留意点と院内スタッフへの周知 一ライセンス制と網羅的院内勉強会の導入一}

\author{
岸本 寛史 ${ }^{1)}$, 小島 一晃 ${ }^{2)}$, 原武 麻里 ${ }^{3)}$, 藤原 和子 ${ }^{3)}$, \\ 岩井真里絵 ${ }^{2}$, 石丸 正吾 ${ }^{1)}$, 金村 誠哲 ${ }^{1)}$
}

1) 高槻赤十字病院 緩和ケア診療科部,2) 同 薬剤部, 3) 同 看護部

受付日 2014 年 5 月 14 日 / 改訂日 2014 年 5 月 30 日 / 受理日 2014 年 6 月 12 日

アブストラル ${ }^{\circledR}$ 舌下錠は, フェンタニルの速放製剤と位置づけられるが, その用法・用量の調整は, 従来のオピオイド製剤 と異なる点が多い. 留意点として, 本剤の増量がレスキュー・アップであることを意識した用量調整, ベース量に見合った 1 回投与量の上限の目安の設定, レスキュー投与と追加投与の区別, その間隔や回数についての制限の周知, コストなどが 挙げられる.これらを鑑みて，当院では，原則として経口摂取が難しくなってきた患者で持続注射が導入されていない入院 患者を適応とした. 緩和ケアチーム・薬剂部・看護部が協カして上記留意点の周知を図った. 医師向けの講習会を診療科ご とに開催し、講習を受けた医師のみが処方できるライセンス制を導入し, 医師から看護師への指示を標準化した. また, 看護 師をはじめとする医療スタッフ向けに 10 回の勉強会を開催した. 処方後は, 薬剤部と緩和ケアチームによるモニタリング も行う体制を整えた。

Palliat Care Res 2014; 9(3): 911-5

Key words: フェンタニル舌下錠, レスキュー・アップ, ライセンス制, 網羅的勉強会

\section{緒 言}

アブストラル ${ }^{\circledR}$ 舌下錠 (以下, ABS) は, 2013 年 12 月に発売と なった経粘膜吸収性フェンタニル製剤で, フェンタニルの速放 製剤と位置づけられるが, その用法・用量調整については, 従 来のモルヒネ・オキシコドンの速放製剤と異なる点が多くあ り,さまざまな注意が必要である。

本稿では, ABS の使用における問題点と留意点について考 察し, 高槻赤十字病院 (以下, 当院) で行った院内スタッフへの 周知法を報告する.

\section{ABS 使用時の問題点と留意点}

\section{1 レスキュー・アップとベース・アップ}

疼痛のコントロールにおいては, タイトレーションによって ベース量を調整し，それに見合うレスキュー量を適宜調整する， というのが従来のやり方である ${ }^{1}$. ところが, ABS に関しては, 「定時投与オピオイド鎮痛剤の投与量」(ベース量) と「アブス トラル ${ }^{\circledR}$ 舌下錠至適用量」の間には相関性が認められなかった として, 突出痛のコントロールにおいては, ベース量に言及す ることなく注1) $\mathrm{ABS}$ の増量を勧めている21. それがレスキュー・ アップであることを意識しておかないと, 特にベース量が少な い場合は, レスキューだけが突出するいびつな処方になる危険 がある注2). 用量調整の際, ベースとレスキューのどちらを上げ る方が良いかは, その都度判断する必要があるが, メーカーの
推奨では,この点が見落とされやすいと懸念される.

\section{1 回投与量の目安}

従来, レスキュー薬については,「経口・静脈内・皮下投与の いずれにおいても, オピオイドの 1 日投与量の 10 - $20 \%$ 相当 の量を投与しており,この投与量は安全かつ有効であることが 示唆される」1) とされてきた.

ABS の添付文書には「1 日に 4 回を超える突出痛の発現が 続く場合には,がんに伴う持続性疼痛に使用されているオピオ イド鎮痛剤の増量を検討すること」と書かれている. 1 日に 4 回を超える突出痛が続くまでは, (ベース量にかかわらず) ABS の増量で対応するように勧めていると受け取れる. 従来の原則 に従って安全性を重視するのであれば, たとえば 1 日投与量の $1 / 6$ を目安として ABS の 1 回投与量の上限の目安を設定して おくことが必要ではないだろうか.

\section{3 投与間隔と投与回数}

オプソ ${ }^{\circledR}$ (モルヒ市塩酸塩水和物), オキノーム ${ }^{\circledR}$ (オキシコド ン塩酸塩水和物) については, 病棟の看護師へも, 患者へも「1 時間以上空ければ反復投与可」というシンプルな指示でよ かった. しかし, ABS の場合, レスキュー投与の間隔は 2 時間 以上注3) で, 回数は 1 日 4 回まで, 追加投与はレスキュー投与か ら 30 分以降に 1 回のみ許されている (以下, 各突出痛に対す る最初のレスキュー投与を「レスキュー」, 各「レスキュー」 の 30 分以降に 1 回のみ許されている追加投与を「追加」と呼

Corresponding author: 岸本寛史 高槻赤十字病院 緩和厅ア診療科部 干 569-1045 大阪府高槻市阿武野 1-1-1

TEL 072-696-0571 (代) FAX 072-690-1228 E-mail: momokish@gmail.com 


\section{表 1 当院でのアブストラル ${ }^{\circledR}$ 使用の方針}

(1) 導入は入院患者に限定. 外来での処方は入院で導入され た患者に限る。

(2) アブストラル ${ }^{\circledR} の$ 導入は, 原則として, 経口摂取が難しく なってきた患者とし, ベース量にかかわらず $100 \mu \mathrm{g} /$ 回 から開始する.

※ベースの薬剤がフェンタニル貼付剤の患者でも, 経 口摂取が可能であれば, レスキュー薬は従来どおり オキノーム ${ }^{\circledR} \cdot$ オプソ ${ }^{\circledR}$ とする

(3) 効果が不十分な場合には, ベース・アップとレスキュー・ アップ (アブストラル $\left.{ }^{\circledR}\right)$ のどちらが良いかをその都度判 断する.

(4) アブストラル ${ }^{\circledR} の$ 増量に際しては, 1 回投与量の上限の 目安 (表 2) を参照する.

(5) オキノーム ${ }^{\circledR} \cdot$ オプソ ${ }^{\circledR}$ との併用は避ける.

表 2 ベース量から推定されるアブストラル ${ }^{\circledR} 1$ 回 投与量の上限の目安

\begin{tabular}{cc}
\hline フェントス ${ }^{\circledR}$ & アブストラル $^{\circledR}$ \\
\hline $1 \mathrm{mg}$ & $50 \mu \mathrm{g}^{*}$ \\
\hline $2 \mathrm{mg}$ & $100 \mu \mathrm{g}$ \\
\hline $4 \mathrm{mg}$ & $200 \mu \mathrm{g}$ \\
\hline $8 \mathrm{mg}$ & $400 \mu \mathrm{g}$ \\
\hline
\end{tabular}

*50 $\mu \mathrm{g}$ の製剤はないため, $100 \mu \mathrm{g}$ を使用する

んで区別する). 開始量はベース量にかかわらず $100 \mu \mathrm{g}$ で, 1 回投与量の上限も設定されている.

ここで, 従来にはなかった「レスキュー」と「追加」の区別, $「 2$ 時間」と「30 分」という 2 種類の時間間隔, 1 日 4 回まで という回数制限など, 考慮に入れる心゙き変数が, オプソ ${ }^{\circledR}$, オキ ノーム ${ }^{\circledR} に$ 比べてはるかに多くなり, その指示も複雑になる. これを医療者に周知させるには, かなりの周到な準備が必要で あり,まして, 患者・家族に理解してもらうのは, さらにハード ルが上がる。

また, 1 回の突出痛につき,「追加」は 1 回のみとされている が, 実際には, 突出痛と持続痛とは明確に区別できないことも 多く, 臨床現場では「レスキュー」と「追加」の区別に迷う場 面も想定される.また,「レスキュー」を行う時には, 前回の 「レスキュー」(T1)の時刻を把握しておく必要があるが,「追 加」(T2) がなされた場合には, 直前の時刻 T2 ではなく, 2 回前 の時刻 $\mathrm{T} 1$ を覚えておく必要があり, 病棟スタッフ, 特に看護 師一の周知と, 患者・家族への周到な説明が求められる. ある 程度の理解力があり, また身体的にも心理的にも余裕がなけれ
ば,使いこなすことは難しいと予想される.

\section{4 コスト}

コスト面でも, 1 錠あたり, ABS $100 \mu \mathrm{g}$ は 573 円で, オキノー ム ${ }^{\circledR} 2.5 \mathrm{mg}$ が 65 円, オプソ ${ }^{\circledR} 5 \mathrm{mg}$ が 120 円と比べると, ABS は 突出している.

\section{当院における ABS の適応}

これらの問題点と, 舌下投与という投与経路のメリットを勘 案し, 表 1 のような方針を設定した. 具体的には, イレウス, 放 射線治療, 化学療法などで経口摂取が不可となり, オピオイド の貼付剤で疼痛コントロールを行う場合にレスキューとして 使用する, といったケースが良い適応と思われる.

\section{ABS 使用に関する留意点の周知}

スタッフが ABS を安全に適正に使用できるよう, 緩和ケア チーム (以下, PCT), リスクマネージャー, 看護師長一薬剤師連 絡会で討議を行い, 周知すべき要点をまとめ, 導入までのス テップを整理し, サポート体制を整えて, 下記のように周知を 図った。

\section{1 主治医への周知}

医師に関しては, 診療科単位で講習会を行い, 前記留意点と 当院における方針, セット化した処置指示 (後述) の出し方を 伝え, 受講者にのみ処方権を与えるライセンス制を導入した。 実際には, 呼吸器内科 - 外科, 消化器内科, 外科, 血液内科, 泌尿 器科, 産婦人科の各カンファレンスに出向き, $15-30$ 分程度の 時間を割いてもらい, 講習を行った. 講習を受けた医師につい ては電子カルテに処方権を登録し,ライセンスを持たない医師 はABS の処方ができない仕組みとした.

処方・指示オーダーについては, 診療科ごとにばらつきがあ ると現場の看護師の混乱を招くため, 以下のように定型指示を 作成し, セット化することで院内での統一を図った.

入院処方は, 「入院用」を選択し, 1 回量 $\times$ 回数の形で必要量 を指定するだけで,「入院処置指示に別途指示あり」などの処 方コメントが自動的に入力される (図 1 上段). 次に, 「入院処 置指示」にセット登録されている「アブストラル」の項目を 選択すると, 看護師向けの詳細指示が定型指示として自動的に 入力されるので, 処方医はその中の 1 回レスキュー量と追加投 与量を指示する (図 1 下段). 途中で用量変更を行う時は, 錠剤 の規格が同じであれば入院処置指示画面の 1 回レスキュー量 や追加投与量のみを修正し, 規格が变わる場合は処方オーダー

\footnotetext{
注1) 低用量 (モルヒネ経口剤 $60 \mathrm{mg} /$ 日未満) の場合には慎重を期すとの記載はあるが, ベース・アップについての言及はない.

注2) たとえば, フェントス ${ }^{\circledR} 1 \mathrm{mg}$ を貼付している患者が, 1 日 3 回の突出痛に対してアブストラル ${ }^{\circledR} 100 \mu \mathrm{g}$ を 3 回使用し, うち 2 回は 30 分後 の追加投与が必要であったとすると,メーカーの推奨によれば, アブストラル ${ }^{\circledR} の 1$ 回投与量を $200 \mu \mathrm{g}$ に増量することになる.これは, モ ルヒネに置き換えれば, MS コンチン (モルヒネ硫酸塩水和物徐放剂) $30 \mathrm{mg} /$ 日を内服している患者がオプソ ${ }^{\circledR} 20 \mathrm{mg} /$ 回を使用することに 相当する. しかし, 従来の考え方からすれば, これだけレスキューが必要ならべースが足りていないと考えて, まず徐放製剤を増量するで あろう.フェンタニルは即効性がある分, 副作用も寸ぐに出やすいと考えられ, ベース量と切り離して用量調整を行うのではなく, ベース 量に見合った上限の目安の設定を強調すべきではないかと考える.

注3) レスキュー間隔が, アブストラル ${ }^{\circledR}$ では 2 時間以上に対し,イーフェンバッカル錠 ${ }^{\circledR}$ は 4 時間以上となっているのも, 現場に混乱を生じさ せる要因である.
} 


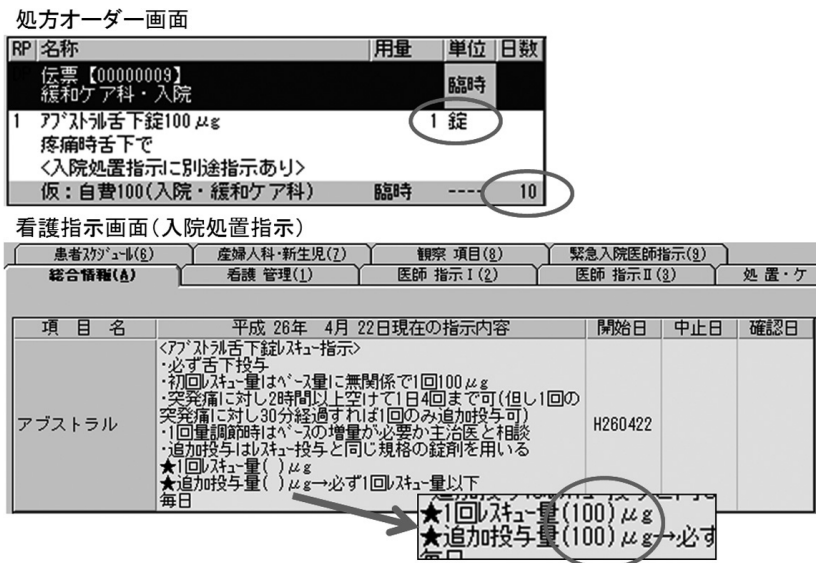

図 1 指示画面 (入院用)

も併せて指示し直すことになる。

退院・外来処方については, 「退院・外来用」を選択し, 1 回 レスキュー量 $\times$ 回数および追加投与量を指示すれば, セット化 された患者向けの定型指示が処方コメントという形で自動入 力される (図 2). 追加投与量の指示をしない場合は, 追加投与 関連の用法コメント行を削除寸ればよい, 退院・外来用は, 処 方コメントとして詳細指示が入るため, 院外処方箋・薬袋を通 して患者に反映される仕組みとなる。

以上の取り組みにより, ABS の処方の留意点について周知 し,また看護師への指示も標準化して混乱が生じないようにし た.

\section{2 看護師への周知}

看護師への周知は, (1)師長会で周知方法を提示, (2)全職員を 対象とした全体勉強会, (3)看護師を対象とした病棟ごとの勉強 会,の順に行った. 当院には緩和ケアリンクナースがいないた め, まず, 師長会で看護管理者を通じて ABS について周知を促 す働きかけをした. ABS は, 従来のレスキュー製剤と用法・用 量が異なり, 現場の混乱が予測されるため, 安全に適正に投与 できるよう, スタッフ 1 人ひとりが理解する必要性を伝え, 師 長には, スタッフへ全体勉強会, 病棟勉強会への参加を促す役 割を担ってもらうよう依頼した。

次に, PCT の医師・薬剤師・看護師による全体勉強会を 2 回開催し, 全看護師の約 $1 / 4$ が参加した.さらに, 主治医対象の 講習会と並行して, 関連病棟で看護師対象の勉強会を開催し た. 病棟勉強会は, PCT 看護師が担当し, 多くの看護師が受講 できるよう, 各病棟の都合に合わせて勉強会を複数回行った (5 病棟で計 8 回の勉強会を開催した. 全体勉強会への参加が少な かった病棟では, 複数回の勉強会を行って周知を図った). 勉強 会では, 突出痛とアセスメント, 製剤の特徵, 用法, 従来のレス キュー製剤との違い, 副作用, 実際の投与の流れ, 患者・家族へ の説明, 投与後の評価, 看護師の役割, サポート体制について説 明した. 薬剤の使用方法だけでなく, スタッフががん性疼痛の ある患者に質の高い看護を提供できるよう, 看護の視点を強調 した.

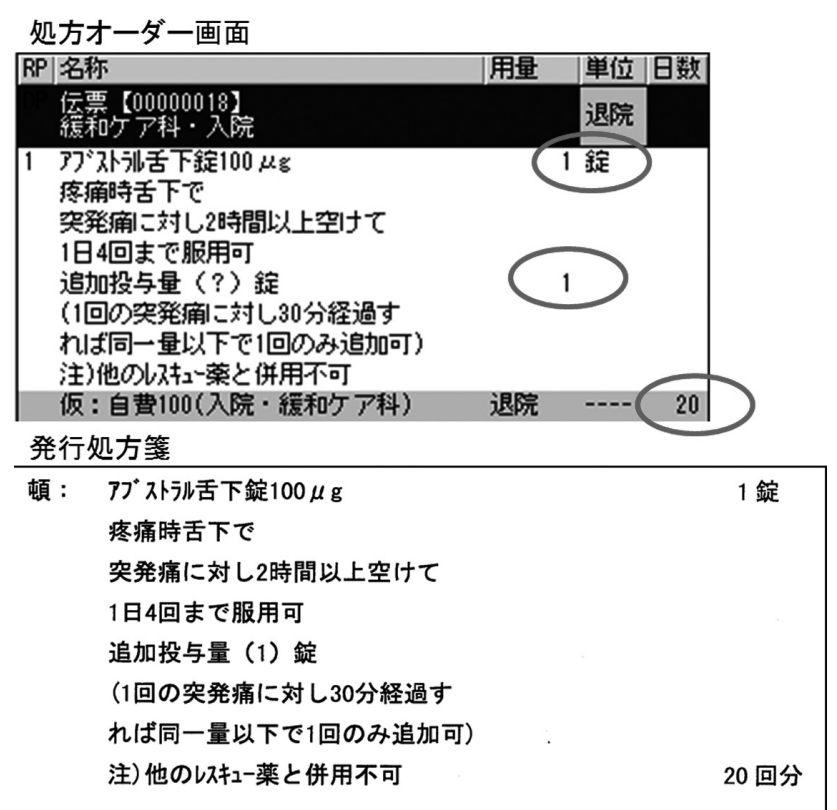

図 2 指示画面 (退院・外来用)

\section{3 薬剤部における対応}

ABS が処方されたケースについては, PCTにも院内メール にて連絡を入れ, 薬剤部と PCT の双方で使用方法, 効果, 副作 用などのモニタリングを行うこととした.また, 調剤の際に, フェントス ${ }^{\circledR}$ (フェンタニルクェン酸塩) の用量 (ベース量) と ABS の用量 (レスキュー量) のバランスを, 当院の使用方針 (表 1)に従い, 画一的に調剤者が確認し, 過剩投与を防ぐ体制を とった.

\section{結 論}

$\mathrm{ABS}$ の使用時の留意点と当院における使用方針, その周知 法についてまとめた. 前述のごとく, PCT ・看護部・薬剤部を 中心に, 院内スタッフへの周知を徹底し, 指示を標準化したが, 今後の課題として, 患者・家族一の教育, 入院中に導入された 患者が外来で継続処方を受ける場合の調剂薬局への周知と いった問題が挙げられる.

前者については, 患者のコンプライアンスを考慮した用法・ 用量の簡略化を検討する必要があるかもしれない. また, 後者 については, 当院では, すべての一般病棟に常駐薬剤師を配置 し, 退院時に調剂薬局一服薬遵守・副作用などを含めた情報提 供書を交付しており, 本書をうまく活用し薬薬連携を充実させ ることが肝要であると考えている.

ABS の用法用量調整については, 血中濃度の推移, 半減期 (オプソ ${ }^{\circledR} 5 \mathrm{mg}$ は $2.2 \pm 0.3$ 時, オキノーム ${ }^{\circledR} 2.5 \mathrm{mg}$ は $6 \pm 3.9$ 時, ABS $100 \mu \mathrm{g}$ は $5 \pm 2.5$ 時) を見るかぎり, ABSのみ「レス キュー投与」と「追加投与」を区別し，さらにその投与間隔を 別々に設定しなければならない理由はよく分からない.コンプ ライアンスと安全性を優先させるなら,「レスキュー投与」と 「追加投与」の区別を廃し, 一定の投与間隔と 1 日の投与回数 の上限を設定することを検討しても良いと思われる. 


\section{文 献}

1) 特定非営利活動法人日本緩和医療学会 編. がん疼痛の薬 物療法に関するガイドライン 2010 年版. 金原出版, 東京, 2010; 33: 143-5
2) 協和発酵キリン・久光製薬. アブストラル ${ }^{\circledR}$ 舌下錠総合製 品情報. 2014; 12.

著者の申告すべき利益相反なし 


\title{
Several notices of the usage of sublingual fentanyl tablet $\left(\right.$ Abstral $\left.{ }^{\circledR}\right)$ and its dissemination to the medical stuff in our hospital : Introduction of a license system and an all-inclusive course
}

\author{
Norifumi Kishimoto ${ }^{1)}$, Kazuaki Kojima ${ }^{2)}$, Mari Haratake ${ }^{3)}$, Kazuko Fujiwara ${ }^{3)}$, \\ Marie Iwai ${ }^{2)}$, Shogo Ishimaru ${ }^{1)}$ and Seitetsu Kanemura ${ }^{1)}$
}

1) Department of Palliative Medicine, Takatsuki Red Cross Hospital,

2) Department of Pharmacy, ditto, 3) Division of Nursing, ditto

\begin{abstract}
A recently licensed opioid, Abstral ${ }^{\circledR}$, a rapid-acting sublingual tablet of fentanyl, is different from other opioids in its complicated usage. The points to consider are; a careful titration grounded on the assessment whether the increase of base or rescue is appropriate, setting up the tentative upper limit suitable for the baseline opioid, the differentiation of the concept between the rescue dose and the additional dose, instruction to the medical stuff as well as patients and family and cost benefit balance. Taking account of these points, we recommend introducing Abstral ${ }^{\circledR}$ in our hospital to patients who have difficulty in swallowing or other gastrointestinal function only in the wards.

The palliative care team, the department of pharmacy and the division of nursing collaborated to let the medical stuff know these concerns and introduced a license system in which only those doctors who receive an intensive course on the use of Abstral ${ }^{\circledR}$ can prescribe it. At the same time, we gave a lecture for the nurses and other medical stuff repeatedly (ten times) so as to include as many as possible. A monitoring system of Abstral ${ }^{\circledR}$ prescription is also established in our hospital.

Palliat Care Res 2014; 9(3): 911-5
\end{abstract}

Key words: sublingual fentanyl tablet, rescue up, license system, all-inclusive course 